IBIMA Publishing

Journal of Marketing Research \& Case Studies

http://www.ibimapublishing.com/journals/JMRCS/jmrcs.html

Vol. 2013 (2013), Article ID 197440, 15 pages

DOI: $10.5171 / 2013.197440$

Research Article

\title{
Consumer Purchase Intentions and Honey Related Products
}

\author{
Steven Ho Chiang Yeow, Susan Tee Suan Chin, Jian Ai Yeow and Khong Sin Tan
}

Multimedia University, Malacca, Malaysia

Correspondence should be addressed to: Steven Ho Chiang Yeow; steven910917@hotmail.com

Received 20 January 2013; Accepted 18 May 2013; Published 29 September 2013

Academic Editor: Naila Aaijaz

Copyright (C) 2013 Steven Ho Chiang Yeow, Susan Tee Suan Chin, Jian Ai Yeow and Khong Sin Tan. Distributed under Creative Commons CC-BY 3.0

\begin{abstract}
Honey products have been developing from health supplements field to economic development field. There are numerous of explanations when it comes to exploring the factors that influence consumers to consume honey products. The portrayal of honey congregated importance ever since it has been commonly used in both medical and domestic needs and as well as beauty needs. In peoples' perspective, the quality of the product will be the key success factor of honey product where industries of honey maker faced challenges for making and maintaining as well as preserving of honey products. With the increasing market size and the increasing consumer demand each year, honey makers have to search for new approaches and to learn to understand the consumers' need in order to increase their product satisfaction and customers' loyalty. The purpose of this study is to determine the factors that will influence consumers' purchase intention of honey related products. To facilitate this study, both quantitative and qualitative methods have been employed to gather the data. 200 questionnaires were collected. It was found that Medical condition, Quality of product, Brand Reputation and Pricing do influence the purchase intentions.
\end{abstract}

Keywords: Honey related products, Consumers Purchase Intentions, Consumer Satisfaction.

\section{Introduction}

Honey is a foundation of readily accessible sugars, protein, acids, nitrogen, amino acids, minimal amount of minerals and a number of other micro quantities of modules like pigments, aroma, flavour, phenolic compounds, colloids, sugar alcohol and vitamins (Crane 1975). In peoples' perspective, the quality of the product will be the key success factor of honey product where industries of honey maker faced challenges for making and maintaining as well as preserving of honey products. Nevertheless, honey plays an essential role of contribution towards the medical field as it is generally healthy and popular. With the increasing market size and the increasing consumer demand each year, honey makers have to search for new approaches and to learn to understand the consumers' need in order to increase their product satisfaction and customers' loyalty. 
There have been evidence to support the idea of product packaging can affect the consumers' buying behaviour. All the aspect such as colour, shape, brand belief, designs, brand personality, and brand image plays an important role in affecting consumer's buying behaviour in purchasing honey because consumer do not actually think intensely about all brands at all before they walked into the store to buy. More than 70 percent of purchase decisions are achieved through at the point of sale after a detailed market research is conducted (Connolly and Davidson, 1996). Honey products have been developing from health supplements field to economic development field. It is important that a study be undertaken to examine the perceptions and intentions of consumers in honey related products.

\section{Literature Review}

Honey industry in the world has faced a lot of obstacles such as global weather patterns in Argentina and Chile where the extreme temperatures and dry humidity affect the honey production drastically and the market manipulation of honey prices in Europe. As a result, the US crop is estimated at the end of the year to decline to approximately $150,000,000-160,000,000$ pounds which is one of the lowest crops ever recorded the history of honey production (Phipps, 2012). Beekeeping has never failed to be one of the primogenital forms of animal husbandry the world has ever known. (McNulty et al, 2006).As an implication, honey has been serving as an important benchmark and standard for both consumers and suppliers in the honey industry ever since (Baltrusaityte et al, 2007).

\section{Consumer Intentions}

Consumer behaviour is defined as the behaviour that consumers project in searching for, using, purchasing, evaluating, and disposing of products and services that they assume will satisfy their needs (Pelau, 2011).The term is defined in order to have a better understanding and information on the relationship between consumer behaviour and the marketing concept as well as market segmentation, targeting and positioning (Mothersbaugh pg 11,2010).Customer satisfaction is considered as the top notch of the whole idea of consumer behaviour as it is defined as customers' feelings towards a certain value of the product or service that was received as a result of using a specific organization's proposing in precise use situations which is essential (Woodruff, 1993).

There has been a research showing that most of the consumers usually comprehend themselves bearing with risks instead of benefits. This occurrence is based on "habitualized" behaviour and decision making as most of the consumers always purchase it repeatedly until they are familiarized and place their trust in it which is better known as superior value expected. From the occurrence of sale, customers perceived value were delivered and satisfaction is obtained (Pelau, 2011). According to Phipps (2012), industries that sell natural products tend to generate a connection bond and send confident messages to consumers so that there will be an increase of consumption level, new products are developed, consumers' perception value boosted and the increased entrance of higher quality products into the market.

Occasionally, there are consumers who may want to obtain high quality of food products with unique and exclusive characteristics (Madas et al, 2011). Not over looking that consumers always put their interest and their money into foods that are free from contaminants, pesticides, chemicals and other health risks so that they are somehow able to feel assured in their rational mind (Mintel Organic Foods, 2006, p.1). Some of the consumers that react to this purchase decision making usually based it on their past experience. However, most of the consumers always purchase the product or service based on emotional aspect rather than rational aspect and it's important to capture 
their buying decision by projecting a superior value of the product or service which can be done through mass media and advertising. Consumers are usually influenced not only by economy but psychology as well (Leon 2011). Understanding consumers' behaviour and purchasing patterns especially on product line are extremely crucial in order to create inevitable customers satisfaction level (Leon 2011). Without potential consumers to purchase honey products, there will be a decline in the opportunities for honey makers to survive in the natural food industry (Anton 1995).

\section{Purchase of Honey and Factors Involved}

\section{Quality of Product}

Quality of product is defined as the superiority or excellence of performance and apparent quality of a certain product which can be judged and assessed based on consumers' perception and opinion (Aaker 1991). A typical characteristic of an object to its degree of superiority is known as quality. There are people who favour quality as the originator or determinant of satisfaction because the customers are the one that defines and perceives quality (Cronin \& Taylor, 1992).

Product quality can be examined under two different categories which are quality objectives and perceived quality (Brunso, 2005). Measuring the quality is fixed by intrinsic and extrinsic value. The intrinsic value denotes something that are interrelated to the physical form of the product such as colour, appearance and volume whereas extrinsic value is related to non-physical form of the product such as branding and product information (Zeithaml 1988).

There has been a research done by Anderson and Sullivan in 1993 stating that consumers may have different preferences or obligations with respect to which characteristics of a product quality needs to be improvised simultaneously, and, to what extent it is needed to get a more satisfactory result. This is because the attitudes of the consumers are credentials for satisfaction which links the relationships between quality perceptions and the product itself (Maria, 2003). Attitude of the consumers can either be constructive or inauspicious depending on the quality of product they received (Fishbein \& Ajzen 1975). Therefore, product owners need to determine the missing links and think out of the box to provide solutions and improvisations on the products if it's been found to be under dissatisfactory levels in order to maintain or achieve customers' loyalty (Pearson, 2006).

For a product to achieve its maximum potential quality in order to satisfy consumers, it requires to achieve most of the attributes such as outstanding performance to execute, reasonable price to purchase, durable, easily available everywhere, easily to be service, user friendly, simple as possible, safe, reliable, easy to maintain, aesthetics and easy to dispose._The tool for measuring quality which has been suggested by Petrick (2002) is divided into four sub groups which are quality outstanding, reliability, trustworthiness and consistency. On the other hand, consultation advice from industry experts and product samplings are often the key to maintain a high level quality of the product.

\section{Medical Condition}

Medical condition can be classified as a condition in which the occurrence of a medical problem that needs to be treated or managed (George, 2012). Diseases from major to minor state or even the signs of disease which occurred on an individual are also considered as medical condition. Consciousness on the nutrition, health, and quality of food they eat has become one of the important aspects for consumers before they purchase (Magnusson et al, 2001). The growing health concern levels upsurge the demand for organic food as health seems to be more "priceless" as compared to wealth in 
many peoples' perspectives (Wandel \& Bugge, 1997).

Speaking in terms of traditional medicine, one of the medical wonders that provide dynamic benefits for mankind is the Royal Jelly because it contains a high level of protein, lipids, sugar, various vitamins and anti-microbial properties (Lee et al, 1999). Royal Jelly is made up of hypo pharyngeal glands of worker bees which are in whitish yellow fluid form. Royal Jelly is the crown jewel among the bee hive products (Ong, 2012). The Royal Jelly is actually made only for the Queen Bee to devour (Rasha \& Robinson 2003). Royal Jelly can improve the symptoms of anorexia, fatigue, vitality and general debility. Dr. Albert Saenz of the Pasteur Institute in Paris wrote: "Numerous studies demonstrate the existence of fraction in Royal Jelly which correspond to $97 \%$ of the substance, plus an undermined fraction whose very presence could explain the remarkable and mysterious properties of Royal Jelly. A spoon feed of Royal Jelly can deliver optimum daily intake and also favourable to the consumers' general health (Tamura, 1985).

Commonly, flesh wounds or damages that a certain individual befall can be treated by using honey as it proved to have low $\mathrm{pH}$ levels which enables its capability to help eliminate non-vital tissue from the wound area and stimulate the growth of new tissue (Rasha \& Robinson, 2003). Nevertheless, eye infections which consists of bacteria or microbiological agent triggers the condition of irritation, itchiness and red eyes can actually be treated by using honey due to its antibacterial properties which act as humectants to provide soothing relief (Abdulrahman, 1990).Also, honey is good for sore throat as it contains antimicrobial which smoothen and kills bacteria inside the throat (Kashmir Monitor, 2011). Medical-grade honey served as a heavy-duty combatant against antibiotic resistant pathogens such as Methicillin-resistant Staphylococcus Aureus (MRSA), vancomycin- resistant strains (VRS) and Pseudomonas Aeruginosa (Cooper \&
Molan, 1999). Nevertheless, effective reduction actions in scaring and pain scale on heavily projecting wounds such as diabetic foot ulcers, first and second degree burns, traumatic and surgical wounds can be treated by using honey (Infectives Week, 2009).

Honey has always been contributing in the medical fields by providing varieties of permitted nutritional and health effects which also includes antibacterial, antioxidant, anti-inflammatory, prebiotic and other nutritional value. However, not all honey can provide such benefits due to their different chemical composition and attributes depending on the user (Ong 2012). There are also some honey products that may cause allergy to consumers (Ong, 2012). There have been some consumers that cited allergy when they consumed bee pollen. There were also reports that some consumers developed rashes after consuming bee pollen.

\section{Brand Reputation}

Robertson (1991) suggested that brand reputation is often recognized as one of the most important key roles in the area of marketing which does not only serves as a foundation for strategic marketing-mix subjects but also plays an active role in building long term brand equity. Brand symbolizes the value, identification, term and name of business assets by adding both economic and strategic value into its proprietors (Moisescu, 2011). Reputation is defined as the valuation of the consistency over time of an attribute of a product or service. The valuation is based on the individual's willingness and ability to perform an action frequently and repeatedly in an identical fashion (Herbig, 1995). Attributes that are being evaluated can be in the form of price, quality and marketing skills as one pleased (Robertson, 1991).

Brand development system is important as it's a part of preparation for a firm to enter the competitive market and gain experience 
form stronger competitors' brands. As suggested by Wee (1994), brand development system is divided into five stages:

1. Stage One: Vending through other people's brand. Achieve access to distribution and building up production capacity.

2. Stage Two: Developing own brand. Obtain marketing skills and learning to create customer loyalty through low price.

3. Stage Three: Investing into brands. Refining relationships and bonds, and generating value through brand premium.

4. Stage Four: Involve in direct exporting and foreign investments.

5. Stage Five: Creation of allied or global brands. Protection of market share through improvisation of perceived value.

Value that was built up in a brand which is commonly used by marketers in order to gain market advantage is identified as brand equity (Chahal \& Bala, 2010). In terms of set of assets, brand equity is interrelated with the brand and these assets consist of brand loyalty, brand awareness, brand association and perceived quality (Aaker, 1991). Out of all these assets, brand loyalty is proven to be the strongest influence that leads to brand equity (Atligan \& Akinci, 2005). According to Park, Jaworski and Maclnnis (1986), they specified that a brand reputation should be based on brand concept-image which provides the following benefits:

1. Functional: Actual benefits gained from using a product or service, focus on satisfying consumers' basic needs.

2. Symbolic: Added value of a product or service, emphasizing in the ability to fulfil consumers' inner needs and self-image.

3. Experiential: Personal experience from using the product or service.
Some researchers remarked that consumers' perception of a product's quality and value is based on brand names. The better the brand name is, the higher the recognition given to the consumers to the product or service (Chueh \& Kao 2004). Therefore, brand reputation is an approach to show an individual's uniqueness, power, and status among their social group (Maslow, 1970). At the same time, brand valuation of a company is dominant as it is seen as a beneficial key in the sector of sales, performance and even decision making.

\section{Pricing}

There are evidence showing that consumers believe that higher price of a product leads to better quality (Wathieu \& Bertini, 2007). Pricing decision is very crucial from time to time for a company because this decision creates a significant effect towards the performance of supply chain in regard of market demand, procurement cost, revenues, profits and competitions (Ozelkan \& Lim, 2008). Most of the consumers always take note on price-quality relationship in order to make comparison between the firm's rival before making purchasing decision (Lichten \& Burton 1989). Rao and Monroe (1989) claimed that there is a strong positive relationship that occurred for lower-priced and regularly purchased product but Caves and Greene (1996) debated that there is strong positive relationship between price and quality for habitually purchased product.

Pricing is actually interconnected with advertising because advertising act as a medium to provide comparative information of both similar product of the firm and competitors itself to consumers, thus increasing the price sensitivity (Nelson, 1974). Advertising is able to create product differentiation and uniqueness which is a vital measure for brand equity (Aaker 1991). Researchers found out that the increased exposure to advertisements and billboards reduces the consumers demand for certain brand due to their understanding of advertisement contents of that particular 
brand does not meet their requirements (Anand \& Shachar 2002).

As nutrition knowledge has been expanded and was put as a priority in the science field, many people were pretty well-aware of understanding the assortment and types of foods, their nutritional composition and human dietary in their daily life. Soon from gaining the knowledge, people were somehow able to indicate the relationship between different types and combination of food and the links between good health and food intake (Valentine, 2000). Since then, honey industries have been making giant leaps as an essential food supplement for human (Aparna and Rajalakshmi, 1999). Also, there has been research claiming the price of organic honey is being relatively high in the market demand (Phipps, 2012).

\section{Methodology}

The independent variables identified in this study include the Quality of product, Medical condition, Brand reputation and Pricing. The dependent variable is the Consumers Purchase Intention. The research objectives are:

- To determine the level of understanding of honey and honey related products among Malaysians.

- To investigate the relationship between the quality of products and consumption of honey products.

- To explore the relationship between the medical condition affecting consumption of honey products.
- To define the relationship between the reputation and consumption of honey products.

- To clarify the relationship of pricing affecting the consumption of honey products.

Four hypotheses were developed and they are:

- H1: There is a correlation between quality of product and consumers' purchasing behaviour toward honey products.

- H2: There is a correlation between medical condition and consumers' purchasing behaviour toward honey products.

- H3: There is a correlation between brand reputation and consumers' purchasing behaviour toward honey products.

- H4: There is a correlation between pricing and consumers' purchasing behaviour toward honey products.

The study used both quantitative and qualitative methods to gather the data. A questionnaire has been developed to facilitate the data collection. 250 questionnaires were distributed however only 200 questionnaires were able to be used for the study. The target population were the middle age adults. The questionnaire took about 20 minutes to complete. The present researcher distributed the questionnaires at places where honey related products were sold. 
Table 1: Reliability Test for the Variables

\begin{tabular}{|l|c|c|}
\hline Variables & $\begin{array}{c}\text { Number of } \\
\text { Items }\end{array}$ & $\begin{array}{c}\text { Cronbach's } \\
\text { Alpha }\end{array}$ \\
\hline Quality of Product & 6 & 0.823 \\
\hline Medical Condition & 5 & 0.846 \\
\hline Brand Reputation & 5 & 0.824 \\
\hline Pricing & 5 & 0.781 \\
\hline $\begin{array}{l}\text { Consumers' purchasing } \\
\text { behaviour toward honey } \\
\text { products }\end{array}$ & 4 & 0.770 \\
\hline
\end{tabular}

All of the Cronbach values are more than 0.7. The closer the Cronbach's alpha is to 1 , the higher the internal consistency reliability (Sekaran, 2003). Based on this, there is an internal consistency in terms of the variables.

\section{Descriptive Analysis}

Table 2 shows the demographic profile of the respondents. A majority of the respondents are females. $50.5 \%$ of them are aged between 30 to 45 years of age. $70.0 \%$ of the respondents are Chinese. $72 \%$ of the respondents are married. $57 \%$ of them have a diploma or lower. $51 \%$ of them are salaried employees working for the private sector. $50 \%$ of them have income between RM800 to RM2999. Based on the interviews with the bee producers, they did mention most of their customers are Chinese as honey is used as an alternative treatment for chronic illness such as cough. Also according to them, they claimed that some of their customers who are highly educated believed more in western medication instead of the traditional medications. Also, honey is used as a wholesome drink for all members. 
Table 2: Demographic Profile of Respondents

\begin{tabular}{|c|c|c|c|}
\hline Demographic Profile & Frequency & Percentage (\%) & Cumulative (\%) \\
\hline $\begin{array}{l}\text { Gender } \\
\text { Male } \\
\text { Female } \\
\text { Total }\end{array}$ & $\begin{array}{c}94 \\
106 \\
200 \\
\end{array}$ & $\begin{array}{c}47.0 \\
53.0 \\
100.0 \\
\end{array}$ & $\begin{array}{c}47.0 \\
100.0\end{array}$ \\
\hline $\begin{array}{l}\text { Age } \\
18-29 \\
30-45 \\
46-59 \\
>60 \\
\text { Total }\end{array}$ & $\begin{array}{c}51 \\
101 \\
44 \\
4 \\
200 \\
\end{array}$ & $\begin{array}{c}25.5 \\
50.5 \\
22.0 \\
2.0 \\
100.0\end{array}$ & $\begin{array}{c}25.5 \\
76.0 \\
98.0 \\
100.0\end{array}$ \\
\hline $\begin{array}{l}\text { Race } \\
\text { Malay } \\
\text { Chinese } \\
\text { Indian } \\
\text { Other } \\
\text { Total } \\
\end{array}$ & $\begin{array}{c}33 \\
140 \\
16 \\
11 \\
200 \\
\end{array}$ & $\begin{array}{c}16.5 \\
70.0 \\
8.0 \\
5.5 \\
100.0 \\
\end{array}$ & $\begin{array}{c}16.5 \\
86.5 \\
94.5 \\
100.0\end{array}$ \\
\hline $\begin{array}{l}\text { Marital Status } \\
\text { Single } \\
\text { Married } \\
\text { Widowed } \\
\text { Divorced } \\
\text { Total }\end{array}$ & $\begin{array}{c}45 \\
144 \\
4 \\
7 \\
200 \\
\end{array}$ & $\begin{array}{c}22.5 \\
72.0 \\
2.0 \\
3.5 \\
100.0\end{array}$ & $\begin{array}{c}22.5 \\
94.5 \\
96.5 \\
100.0\end{array}$ \\
\hline $\begin{array}{l}\text { Education Level } \\
\text { Secondary and lower } \\
\text { Pre-U } \\
\text { Diploma } \\
\text { Degree } \\
\text { Master } \\
\text { Doctorate } \\
\text { Total }\end{array}$ & $\begin{array}{c}81 \\
5 \\
28 \\
68 \\
16 \\
2 \\
200\end{array}$ & $\begin{array}{c}40.5 \\
2.5 \\
14.0 \\
34.0 \\
8.0 \\
1.0 \\
100.0\end{array}$ & $\begin{array}{c}40.5 \\
43.0 \\
57.0 \\
91.0 \\
99.0 \\
100.0\end{array}$ \\
\hline $\begin{array}{l}\text { Occupation } \\
\text { Salaried employee (private } \\
\text { sector) } \\
\text { Non-profit organization } \\
\text { employee } \\
\text { Government employee } \\
\text { Family business } \\
\text { Self-employed } \\
\text { Unemployed } \\
\text { Student } \\
\text { Total } \\
\end{array}$ & $\begin{array}{c}102 \\
3 \\
45 \\
6 \\
34 \\
2 \\
8 \\
200\end{array}$ & $\begin{array}{c}51.0 \\
1.5 \\
22.5 \\
3.0 \\
17.0 \\
1.0 \\
4.0 \\
100.0\end{array}$ & $\begin{array}{c}51.0 \\
52.5 \\
75.0 \\
78.0 \\
95.0 \\
96.0 \\
100.0\end{array}$ \\
\hline $\begin{array}{l}\text { Monthly Income } \\
\text { <_RM } 799 \\
\text { RM } 800 \text { - RM } 2999 \\
\text { RM } 3000 \text { - RM } 5999 \\
\text { RM } 6000 \text { - RM } 9999 \\
>\text { RM } 10000 \\
\text { Total }\end{array}$ & $\begin{array}{c}31 \\
100 \\
53 \\
15 \\
1 \\
200 \\
\end{array}$ & $\begin{array}{c}15.5 \\
50.0 \\
26.5 \\
7.5 \\
0.5 \\
100.0\end{array}$ & $\begin{array}{c}15.5 \\
65.5 \\
92.0 \\
99.5 \\
100.0\end{array}$ \\
\hline
\end{tabular}


Table 3 shows the respondents consumption and usage profile. A whopping $46.5 \%$ of the respondents only consume honey once a while. They do not consume honey daily. However, $65.5 \%$ of the respondents have consumed honey for more than 2 years. This shows that consumers do know the benefits of consuming honey but they take it as a form of medication for their illness. Once they have recovered, they will not consuming honey. $45.5 \%$ of the respondents purchase honey for less than RM50. Some of the honey related products are less than RM50 for example the honey drink. Many people consume the honey drink when they have cough or sore throat. Honey soothes the throat very quickly. $5 \%$ of the respondents have purchased honey related products which are more than RM301. These purchases could be the Royal Jelly, it is one of the most expensive honey related product. Of course, consuming the Royal Jelly has some good benefits such as energy and even improves the diabetes.

Table 3: Demographic Profile - Usage and Consumption

\begin{tabular}{|l|c|c|c|}
\hline Demographic Profile & $\begin{array}{c}\text { Frequenc } \\
\text { y }\end{array}$ & $\begin{array}{c}\text { Percentage } \\
(\%)\end{array}$ & $\begin{array}{c}\text { Cumulative } \\
(\%)\end{array}$ \\
\hline Regularity & 13 & 6.5 & \\
Everyday & 39 & 19.5 & 26.5 \\
Weekly & 55 & 27.5 & 53.5 \\
Monthly & 93 & 46.5 & 100.0 \\
Rarely & 200 & 100.0 & \\
Total & & & \\
\hline Duration/ Term of Consuming & 18 & 9.0 & 9.0 \\
Less than 1 month & 32 & 16.0 & 25.0 \\
Less than 1 year & 19 & 9.5 & 34.5 \\
1-2 years & 131 & 65.5 & 100.0 \\
> 2 years & 200 & 100.0 & \\
Total & & & \\
\hline Amount of Purchase & 91 & 45.5 & 45.5 \\
< RM 50 & 75 & 37.5 & 83.0 \\
RM 51 - RM 100 & 24 & 12.0 & 95.0 \\
RM 101 - RM 300 & 10 & 5.0 & 100.0 \\
> RM 301 & 200 & 100.0 & \\
Total & & & \\
\hline
\end{tabular}

\section{Results and Discussion}

As seen in Table 4, all of the independent variables have positive and significant relationships with Consumer Purchase Intentions. All of the p values are less than 0.05 . Based on the correlation testing of the relationships, it can be determined that all of the hypotheses are supported. Among the 4 variables, Quality of Product has the highest $r$ value indicating its importance. This is followed by Medical Condition ( $\mathrm{r}=0.639$ ), Brand Reputation ( $\mathrm{r}=0.587)$ and Pricing $(\mathrm{r}=0.439)$. 
Table 4: Correlation Analysis of the Variables

\begin{tabular}{|c|c|c|c|c|c|}
\hline & & $\begin{array}{l}\text { Quality of } \\
\text { Product }\end{array}$ & $\begin{array}{c}\text { Medical } \\
\text { Condition }\end{array}$ & $\begin{array}{c}\text { Brand } \\
\text { Reputation }\end{array}$ & Pricing \\
\hline $\begin{array}{l}\text { Consumer } \\
\text { Purchase } \\
\text { Intentions }\end{array}$ & $\begin{array}{l}\text { Pearson } \\
\text { Correlation } \\
\text { Sig. (2- } \\
\text { tailed) } \\
\mathrm{N}\end{array}$ & $\begin{array}{r}.670^{* *} \\
.000 \\
200\end{array}$ & $\begin{array}{r}.639 * * \\
.000 \\
200\end{array}$ & $\begin{array}{r}.587^{* *} \\
.000 \\
200\end{array}$ & $\begin{array}{r}.439 * * \\
.000 \\
200\end{array}$ \\
\hline \multicolumn{2}{|l|}{ Hypothesis } & $\begin{array}{r}\mathrm{H} 1 \\
\text { Accepted }\end{array}$ & $\begin{array}{r}\mathrm{H} 2 \\
\text { Accepted }\end{array}$ & $\begin{array}{r}\mathrm{H} 3 \\
\text { Accepted }\end{array}$ & $\begin{array}{r}\mathrm{H} 4 \\
\text { Accepted }\end{array}$ \\
\hline
\end{tabular}

Consumers usually do not trust the product completely until they have gained positive results from their experience or other people. However, it's clearly stated when the quality of the product is praiseworthy or dependable, consumers do not mind and they are willing to pay more for these attributes as they are aware of the quality and virtue (Cronin \& Taylor, 1992; Spreng and Mackoy 1996). Also based on the interview responses with the owners of Natural Bee Breeding Sdn Bhd and Giant B, they said that most of the consumers emphasise more on quality of the product as quality is a very important aspect since there have been a massive breakout of fake honey related products around Malaysia. Fake honey related products harm not only the health of consumers' body but also the market value of the genuine honey industries (Ee, 2012).

Commonly, consumers tend to buy honey related products from honey vendors just for the sake of the health benefits (Ee, 2012). People are now more concerned about health preservation and improvement especially for themselves and their family (Schifferstein \& Oude Ophius, 1998; Tregear et al, 1994). Issues regarding consciousness on the nutrition, health, and quality of food they eat have become one of the important distinctiveness for consumers before they purchase whatever products (Magnusson et al, 2001).

Brand reputation is precisely important for a company to stay competitive in the market. In this case, a robust brand with positive equity can ensure firms to gain and achieve customer loyalty, higher market share, higher margin and communication efficiency whereas an inferior brand will cause the opposite effect (Keller, 1993; Keller and Lehmann, 2003).

Pricing is undeniably considered as one of the important factors that will influence consumers' purchasing behavior on honey related products. Although there are still certain consumers that always take note on price-quality relationship in order to make comparison between the firm's rival before making purchasing decision but at the end, pricing is the computation of service that has been charged accordingly that is worth to the client and they are willing to pay (Lichten \& Burton 1989).

Table 5 shows the regression analysis between the independent variables and Consumers' purchasing intentions on honey related products. Quality of product has the highest forecast value of $\beta=0.367$ and Sig. value of 0.000 . When $\beta$ value is higher, it shows the stronger forecast power and as Sig. value is closer towards 0 it means that, the variable is significant. From the result, Quality of product is the most critical factor that influences Consumers' purchasing intentions on honey related product. Medical condition is the second highest and crucial factor that influences Consumers' purchasing intention on honey related product as the value of $\beta=0.268$ and Sig. value of 0.000 . Pricing is the third highest and important factor that influence Consumers' purchasing 
intention on honey related products as the value of $\beta=0.154$ and Sig. value of 0.009 . Based on the multiple regression analysis, Brand reputation does not influence the
Consumers' purchasing intentions honey related products because the value of $\beta=$ 0.115 and Sig. value of 0.111 .

Table 5: Regression Analysis between the Independent Variables

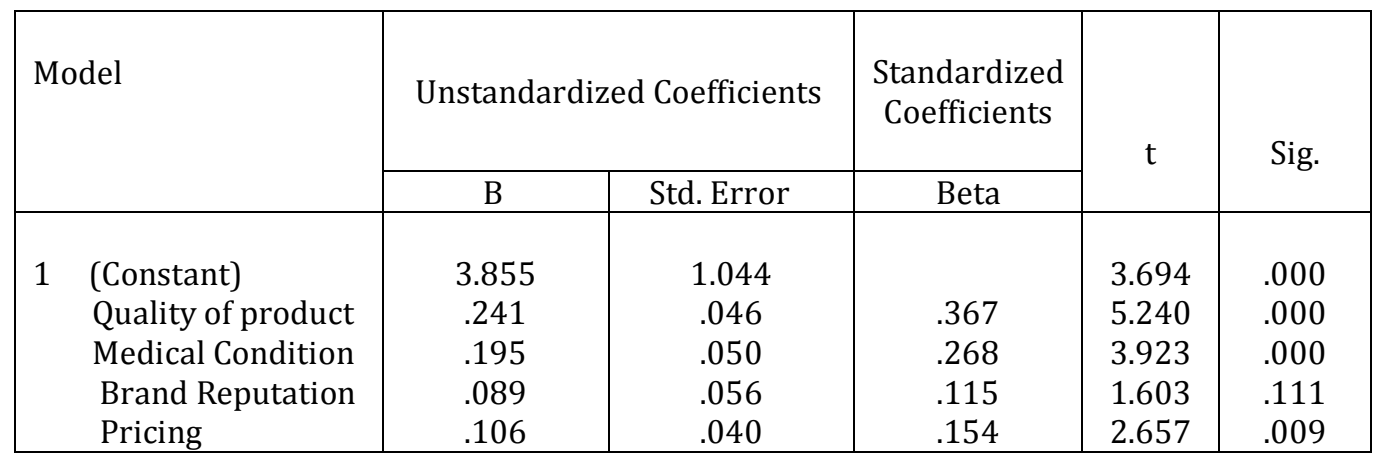

\section{Conclusion and Implications}

From the analysis, it was found that all of the variables have positive and significant relationship with the purchasing behavior of the consumers. Quality, Medical Condition and Pricing have been determined as the main factors that influences the consumers purchasing behavior. Companies need to ensure that their product is of good quality by ensuring that it is hygienically processed. Since consumers will be consuming the product, they need to ensure that the product will not harm their health. Certifications from the relevant help the credibility of the product. Besides that to assure the consumers, marketers need to ensure the products have more information on the labels. Also, it will help the consumers by informing to them the benefits of consuming the product. For example, if the product helps to improve the energy level of the person, this information needs to be stated. Also, if there are any side effects, it should be informed as well. This will assure the consumers and increase their level of confidence.

Through the Health Ministry, the government will be able to maintain the health integrity of the product. Regular inspections will deter unethical producers in producing fake honey. Also, the issuance of certificates helps to ensure and assure, Consumers are assured of the quality of the product. This process ensures that the process and handling are done in a proper manner. To ensure that future producers do not become unethical, the government needs also to be strict and punish the unethical producers heavily. By having heavier summons, it then becomes a deterrent. Besides that, the government could also revoke the company's license. This will ensure adherence. Consuming honey related products is good. However, if the product is not being done in a proper manner, the person will be ill and even worse contract a terminal illness. Some unethical producers use chemical to get the consistency of the honey. These chemical could be lethal and carcinogenic. Also, for the people involved in the honey production process, they need to undergo health checks as well. If these people have some illness, they might pass the bacteria to the product. And if the consumer were to consume that product, they will be unwell as well. As such, the government through the health officials needs to monitor these regularly. Regular inspections keep matters in the proper order. It was found through the analysis that people take some time to accept something different 
and at times, they are not willing to spend much. And also, some consumers tend to take honey only when they have no other alternative. They may not want to consume honey when they are healthy. Society needs to change their perception. People tend to look for alternative treatment as the last resort. Such perception needs to change. At times, consuming honey at the last resort may not help because the illness has become terminal. When its terminal, there is no more cure. As mentioned earlier, Prevention is better than Cure.

The purpose of this study was to determine the factors that will influence consumers purchasing behaviour on honey related products. Honey related products cover a wide range. It includes bee pollen, the famous Royal Jelly and the honey drink. For the purpose of investigating this study, a few research objectives were made. Out of these research objectives, four hypotheses were drawn. Based on the findings and analysis, all of the hypotheses were found to have a positive and significant relationship with the consumers' purchasing behaviour. The four variables identified are Medical condition, Quality of product, Brand Reputation and Pricing. It was also found that people do know about honey and the related products. They are aware of its benefit however, not all of them use it regularly.

\section{Acknowledgment}

The author(s) would like to thank the owners of the bee farms for providing much needed information to complete the study.

\section{References}

Abdulrahman, A. (1990). 'Emirates in the Memory of its Sons,' Retrieved from http://www.emeraldinsight.com/journals.ht $\mathrm{m}$ ?issn $=00346659$ \&volume $=33$ \&issue $=6 \&$ art icleid $=866212 \&$ show $=$ ref
Al-Qassemi, R. \& Robinson, R. K. (2003). "Some Special Nutritional Properties of Honey - A Brief Review," Nutrition \& Food Science, Vol. 33 Iss: 6, pp.254 - 260.

Anand, B. N. \& Shachar, R. (2002). Risk Aversion and Apparently Persuasive Advertising, Harvard Business School Working Paper Series, No. 02-099.

Anderson, E. W. \& Sullivan, M. W. (1993). "The Antecedents and Consequences of Customer Satisfaction," Marketing Science 12 (Spring), 125-143.

Aparna, A. R. \& Rajalakshmi, D. (1991). 'Honey- Its Characteristics, Sensory Aspects, and Application,' Food Review International, 15 (4). 455-471, 60

Atligan, E., Aksoy, S. \& Akinci, S. (2005). "Determinants of the Brand Equity a Verification Approach in the Beverage Industry in Turkey," Marketing Intelligence \& Planning, Vol. 23. No. 3, PP.237-248.

Baltrušaityt, V., Venskutonis, P. R. \& Ceksteryt, V. (2007). "Radical Scavenging Activity of Different Floral Origin Honey and Bee Bread Phenolic Extracts," Food Chemistry, 101: 502-514.

Brunsø, K. (2005). 'Food Quality and Preference,' 2007 - Elsevier

Caves, R. E. \& Greene, D. P. (1996). "Brands' Quality Levels, Prices, and Advertising Outlays: Empirical Evidence on Signals and Information Costs," International Journal of Industrial Organization 14, 29-52

Chahal, H. \& Bala, M. (2010). “Confirmatory Study on Brand Equity and Brand Loyalty: A Special Look at the Impact of Attitudinal and Behavioural Loyalty," Vision, 14(1), 1-12. 
Chueh, T. Y. \& Kao, D. T. (2004). 'The Moderating Effect of Consumer Perception to the Impacts of Country-of-Design on Perceived Quality,' Journal of American Academy of Business, 4(1/2), 70-74.

Connolly \& Davidson (1996). 'The Importance of Packaging Attributes: A Conjoint Analysis Approach,'

Cronin, J. J. \& Taylor, S. A. (1992). "Measuring Service Quality: A Reexamination and Extension," Journal of Marketing, 56(3), 5568.

da Fonseca Correia, E. M. (2003). "The Relationships between Quality Management Practices and Purchasing," Retrieved from http://www.aeca.es/pub/on_line/comunicac iones_xvicongresoaeca/cd/9c.pdf

David, A. A. (1991). 'Managing Brand Equity: Capitalizing on the Value of a Brand Name,' NY: The Free Press.

Dezmirean, D. S., Bonta, V, .Pocol, C. B., Madas, M. N.\& Marghitas, L. A. (2011). "Qualitative Characterization of Romanian Robinia Honey according to the European Directive and its Approaches," Economics, Management and Financial Markets, 6(1), 1206-1212. Retrieved from http://search.proquest.com/docview/86952 9865? accountid $=28110$

Ee, P. W. (2013). 'Talk on Honey, One of the Owners of Natural Bee Breeding,' Sdn Bhd

Fishbein, M. \& Ajzen. I. (1975). 'Belief, Attitude, Intention and Behaviour,' Reading, MA: Addison-Wesley. Available at: http://www.er.uqam.ca/nobel/r26710/LRC S/papers/56.pdf

George, T. (2012). 'Talk on Honey. Specialist and Internal Medicine Psychiatric,' Mahkota Medical Centre Melaka, Malaysia.
Herbig, P. \& Milewicz, J. (1995). "The Relationship of Reputation and Credibility to Brand Success," The Journal of Consumer Marketing, 12(4), 5-5.

Infectives Week. (2009). "Paper Highlights Antimicrobial Effectiveness of Medical-Grade Honey in Topical Wound Care," August 10, (2009). Retrieved from http://www.highbeam.com/doc/1G1205135306.html

Kashmir Monitor (2011). 'Health Benefits of Honey,' Retrieved from http://search.proquest.com/docview/89475 9305? accountid=28110]

Keller, K. L. (1993). "Conceptualizing, Measuring, and Managing Customer-Based Brand Equity," Journal of Marketing, 57(1), 11.

Keller, K. L. \& Lehman, D. R. (2003). 'How Do Brands Create Value?,' Marketing Management, vol.12, No.3, pp.26-31.

Kotler, P. \& Keller, K. L. (2006). "Creating Customer Value, Satisfaction, and Loyalty," Pearson Education Retrieved from http://wps.pearsoncustom.com/wps/media /objects/2426/2484677/MKT101_Ch04.pdf

Lee, A. L., Yeh, M. I., Wen, H. M., Chern, J. C., Lin, J. S. \& Hwang, W. I. (1999). 'The Application of Capillary Electrophoresis on the Characterisation of Protein in Royal Jelly,' Journal of Food and Drug Analysis, Vol.7 No.1 pp73-82.

Leon, M. E. et al. (2011). "AGRICOH: A Consortium of Agricultural Cohorts," Retrieved from http://www.ncbi.nlm.nih.gov/pmc/articles/ PMC3108113/ 
Lichtenstein, D. R. \& Burton, S. (1989). "The Relationship between Perceived and Objective Price - Quality," Journal of Marketing Research, 26, 429 - 443.

Magnusson, M. K., Avrola, A., Hursti, U.- K. K., Aberg, L. \& Sjoden, P.- O. (2001). "Attitudes towards Organic Foods among Swedish Consumers," British Food Journal, 103(3), 209-226.

Maslow, A. H. (1970). Motivation and Personality, Harper and Row, New York, NY. Retrieved from https://www.iei.liu.se/fek/frist/fek1hel/maf o/artikelarkiv/1.../B4.pdf

McNulty, M. (2012). "How Products are Made," Available at: http://www.madehow.com/Volume5/Honey.html\#b

Mintel Organic Foods. (2006). "Generation Y Consumer Choice for Organic Foods," p.1, Retrieved from, http://www.jgbm.org/page/6\%20Kristen $\%$ 20Regine.pdf

Moisescu, O. I. \& Vu, D. A. (2011). 'A Conceptual Review on Building, Managing and Accessing Brand Loyalty,' Review of Economic Studies and Research Virgil Madgearu, 4(1), 67-87.

Mothersbaugh, H. (2010). 'Consumer Behaviour 11th Edition,' pg 11,

Nelson, P. (1974). "Advertising as Information," Journal of Political Economy, Vol.81 pp729-54.

Ong (2012). 'Talk on Honey, Owner of Giant B,' Sdn Bhd

Özelkan, E. C. \& Lim, C. (2008). “Conditions of Reverse Bullwhip Effect in Pricing for PriceSensitive Demand Functions," Annals of Operations Research, 164(1), 211-227.
Park, C. W, Jaworski, B. J. \& Maclnnis, D. J. (1986). "Strategic Brand Concept-Image Management," Journal of Marketing, 50(4) October, pp.135-145.

Pelau, C. (2011). 'Analysis of Consumer Behaviour for Different Product Groups,' Management \& Marketing, 6, 101-114.

Petrick, J. F. (2002). “Development of a MultiDimensional Scale for Measuring the Perceived Value of a Service," Journal of Leisure Research, 34(2), 119-134.

Phipps, R. (2012). 'International Honey Market Report for the American Honey Producers Association,' Available at: http://www.americanhoneyproducers.org/ Members/IHMR-Jan2012.pdf

Rao, A. R. \& Monroe, K. B. (1989). "The Effect of Price, Brand Name, and Store Name on Buyers' Perceptions of Product Quality: An Integrative Review," Journal of Marketing Research, vol.16, (August), 351-357.

Robertson, K. R. (1991). 'Book Reviews: Managing Brand Equity - Capitalizing on the Value of a Brand Name,' Sloan Management Review, 33(1), 94-96.

Roy, D., Marinos, E. T., Jan, L. \& Anton, R. (1995). "World Agriculture and Climate Change: Economic Adaptations," Available at http://purl.umn.edu/33933

Schifferstein, H. N. J. \& Oude Ophius, P. A. M. (1998). "Health-Related Determinants of Organic Food Consumption in the Netherlands," Food Quality and Preference, 9 (3), 119-133

Sekaran, U. (2003). 'Research Method for Business: A Skill Building Approach,' 4th edition, John Wiley \& Sons. 
Spreng, R. A. \& Mackoy, R. D. (1996). “An Empirical Examination of a Model of Perceived Service Quality and Satisfaction," Journal of Retailing, Vol. 72(2), pp. 201-214.

Tamura, T. (1985). 'Royal Jelly from the Standpoint of Clinical Pharmacology,' Honeybee Science, Vol.6 No.3 pp117-24 Theory of Reasoned Action (TRA), the Theory of Planned Behaviour (TPB) and the TransTheoretical Model (TTM) to study and predict health related behaviour change. Retrieved from http://www.nice.org.uk/nicemedia/live/118 68/44524/44524.pdf

Tregear, A., Dent, J. B. \& McGregor, M. J. (1994). "The Demand for Organically-Grown Produce," British Food Journal, 96 (4), 21-26.

Valentine, G. (2000). 'Consuming Geographies: We are Where We Eat,' London: Routledge, Retrieved from journals.cambridge.org/abstract_S00380385 00360230

Wandel, M. \& Bugge, A. (1997). "Environmental Concern in Consumer Evaluation of Food Quality," Food Quality and Preference, 8 (1), 19-26.

Wathieu, L. \& Bertini, M. (2007). "Price as a Stimulus to Think: The Case for Willful Overpricing," Marketing Science, 26 (1), 11829.

Wee, C.- H. (1994). "National Branding Strategies and Economic Development: Implications for NIEs and LDCs," The International Executive, 36: 119-145.

Woodruff, R. B., Schumann, D. W. \& Gardial, S. F. (1993). 'Understanding Value and Satisfaction From Customer's Point of View,' Survey of Business, 28pg 33-40

Zeithaml, V. A. (1988). "Consumer Perceptions of Price, Quality, and Value: A Means-End Model and Synthesis of Evidence," Journal of Marketing, 52(3), 2-22. 